\title{
REQUESTIVE STRATEGIES OF INDONESIAN EFL LEARNERS
}

\author{
Meliyawati \\ Department of English Education, Faculty of Teacher Training and Education \\ The University of Kuningan, Indonesia \\ E-mail: meliyawati.melmel@gmail.com \\ Fahrus Zaman Fadhly \\ Department of English Education, Faculty of Teacher Training and Education \\ The University of Kuningan, Indonesia \\ E-mail: fahruszf@gmail.com
}

APA Citation: Meliyawati \& Fadhly, F. Z. (2015). Requestive strategies of Indonesian EFL learners. Indonesian EFL Journal, 1(2), 212-223

Abstract: This study aims to investigate the realizations of requestive strategies used by Indonesian EFL learners. The respondents are 25 of junior students of the Department of English Education in the University of Kuningan. The data were collected through Discourse Completion Test (DCT) and interview. The collected data were analyzed by using the requestive strategies theory by Blum-Kulka, House, and Kasper (1989). The query preparatory is the most term of requestive strategy type used by Indonesian EFL learners in Department of English Education in some different situations on DCT (64.8\%). Second is mild hints with $13.6 \%$, third is mood derivable with $10.4 \%$, forth is obligation statement with $7.5 \%$, fifth is want statement with $2.4 \%$, sixth is suggestory formulae with $1.1 \%$, seventh is hedge performative with $0.3 \%$ and the last are performative and strong hints with nothings. The respondents incline used requestive strategies which is avoid conflict or threatening to the hearer. The study reveals that the social variables such as power, social distance and ranking of imposition really affect toward the realization of requestive strategies used by Indonesian EFL learners.

Keywords: Requestive strategy, Indonesian EFL learners, Discourse Completion Test.

\section{INTRODUCTION}

Language is used as a tool of communication in doing activites in social life. By using language, people can interact with others, communicate and also they can express their thought and feeling to another. They used language to convey a message what they want. But Blum-Kulka, House and Kasper (1989) explain that the minimal units of human communication are not linguistic expression, but rather the performance of certain kinds of acts, such as making statements, asking questions, giving directions, apologizing, thanking and so on. One of basic distinctions offered is between direct speech acts, where the speaker says what he/she means, and indirect speech acts where he/she means more than or something other than what he/she says.

Rue \& Zhang (2008, p. 1) say "a request is to ask someone to do/not do something or to express the need or desire for something.
The interactional goals are represented by particular speech acts such as requests, apologies, compliments, refusals, disagreements, and the like."

While, Schauer (2009) states that requests are very frequent in language use (far more frequent, for example, than apologizing or promising); requests are very important to the second language learner; they have been researched in more detail than any other type of speech act; they permit a wide variety of strategies for their performance; and finally, they carry with them a good range of subtle implications involving politeness, deference, and mitigation.

Brown and Levinson (1987) describe the speech act of a request has been considered a noteworthy subject for the research of speech acts because requests are 'Face-Threatening Acts (FTAs)' which entail an imposition on the addressee: the purpose of a request is to 
get the addressee to do something.

Sometimes people use the marker 'please' when he/she request something to others.

Stubbs (1983 cited in House 1989) states that in English the marker please in fact occurs exclusively with utterances which are interpret able as request; i.e., it does not appear in assertions, promises, offers, invitations, threats, etc.

According to Brown and Levinson (1987, p. 74) "The requestive strategies are included politeness strategy because when people are asking for requesting people should know when they request, how they request and to whom they request." They point out that there are three factors that include into politeness strategy such as social distance (D), power (P) and ranking of imposition (R). They also describe social distance as the distance of social relationship between the speaker and the hearer. They argue the degree of familiarity or solidarity they share (a symmetric relation). Power (P), according to them, is that the speaker's respect to the hearer in effect, the degree to which the speaker can impose his/her will on the hearer (an asymmetric relation). Then they also explain that ranking of imposition (R) in the culture in terms of the expenditure of goods and or services by the hearer, the right of the speaker to perform the act, and the degree to which the hearer welcomes the imposition.

Blum-Kulka, House and Kasper (1989) classifies request on a nine-point scale of mutually exclusive categories. There are nine requestive strategies (1)Mood Derivable: Utterances in which the grammatical mood of the verb in the utterance marks its illocutionary force as a request (Clean up the kitchen). (2) Performative: The illocutionary force of the utterances is explicitly named by the speakers (I'm asking you to move your car). (3) Hedged performative: Utterances embedding the naming of the illocutionary force (I would like to ask you to move your car). (4) Obligation Statement: the illocutionary point is directly derivable from the semantic meaning of the locution (You'll have to move your car). (5) Want Statement: The utterance expresses the speaker's intentions, desire or feeling (I would like you to clean the kitchen). (6) Suggestory

formulae: The sentence contains a suggestion to X (How about cleaning up?). (7) Query

Preparatory: Utterance contains reference to preparatory conditions as conventionalized in any specific language (Could you clean up the mess in kitchen?). (8) Strong hints: Utterance contains partial reference to object or to elements needed for the implementation of the act (You've left the kitchen in a right mess). (9) Mild hints: utterance that make no reference to the request proper but are interpretable through the context as requests (We don't want any crowding) (as a request to move the car).

To make clear about requestive strategies of Indonesian EFL learners, this study involved 25 respondents of junior students of department of English education in University of Kuningan to answer the two research questions: (1) what are kinds of requestive strategies used by Indonesian EFL learners? and (2) how do power, social distance and ranking of imposition infleunce on the realization of requestive speech act?

\section{METHOD}

In this study, qualitative method is used as method design. This study involved 25 junior students of department of English education in University of Kuningan, Indonesia as respondents. The participants are chosen by using purposive sampling. Fraenkel and Wallen (2009) state that purposive sampling is different from convenience sampling in that researchers do not simply study whoever is available but rather use their judgment to select a sample that they believe, based on prior information, will provide the data they need.

The disparity of student's ability in mastering speaking was selected hopefully to extend important information and also give a qualified data because it can show the influence of the performance in asking for requesting. The respondents are chosen based on some considerations.

Discourse Completion Test (DCT) and interview were used to collect the data. Discourse Completion Test (DCT) is used to collect the data. "DCT is a form of questionnaire making use of some natural 
situations in which the respondents are expected to respond by making requesting. Ideally, all data should come from natural conditions" (Blum \& Kulka, House, and Kasper 1989, p. 13). They are given 15 requestive expressions with different situations. The respondents are asked to relate to the situation and express their normal language interaction in such situations.

Besides DCT, the interview was held to know their reason about requesting which related with social variables such as power $(\mathrm{P})$, social distance $(\mathrm{D})$, and ranking of imposition (R). Brown and Levinson (1987, p. 74) "The requestive strategies are included politeness strategy because when people are asking for requesting people should know when they request, how they request and to whom they request." They point out that there are three factors that include into politeness strategy such as social distance (D), power (P) and ranking of imposition (R). They also describe social distance as the distance of social relationship between the speaker and the hearer. They argue the degree of familiarity or solidarity they share (a symmetric relation). Power (P), according to them, is that the speaker's respect to the hearer in effect, the degree to which the speaker can impose his/her will on the hearer (an asymmetric relation). Then they also explain that ranking of imposition (R) in the culture in terms of the expenditure of goods and or services by the hearer, the right of the speaker to perform the act, and the degree to which the hearer welcomes the imposition.

The interview taken from five questions which include about social variables. The researcher conducts face to face interviews with participants, interviews participants by telephone, or engage in focus group interviews with six to eight interviewees in each group (Creswell, 2009). The interview conducted in group interviews with four and five interviewees in each group.

\section{RESULTS AND DISCUSSION}

Based on the data, from 15 situations on DCT which was spread to the 25 participants, produce result 375 utterances. The 375 utterances are classified into nine requestive strategies. The result of analysis from BlumKulka's theory (1989) arranged from the highest percentage to the lowest. Query Preparatory is the most term used by Indonesian EFL learners in Department of English Education in some different situations on DCT (64.8\%). It is followed by mild hints term (13.6\%). And the third followed by mood derivable (10.4\%), the forth followed by obligation statement with $(7.5 \%)$. Fifth followed by want statement with $(2.4 \%)$ and the next followed by suggestory formulae with (1.1\%). And the last is hedge performative $(0.3 \%)$, while performative and strong hints is nothing. The detail description of requestive strategies will be shown in the table below :

Table 1. The distribution of requestive strategies used by Indonesian EFL learners at department of English education University of Kuningan

\begin{tabular}{|c|c|c|c|}
\hline No & Requestive Strategies & Frequency & $\%$ \\
\hline 1 & Query Preparatory & 243 & $64.8 \%$ \\
\hline 2 & Mild Hints & 51 & $13.6 \%$ \\
\hline 3 & Mood Derivable & 39 & $10.4 \%$ \\
\hline 4 & Obligation Statements & 28 & $7.5 \%$ \\
\hline 5 & Want Statements & 9 & $2.4 \%$ \\
\hline 6 & Suggestory Formulae & 4 & $1.1 \%$ \\
\hline 7 & Hedge Performative & 1 & $0.3 \%$ \\
\hline 8 & Performative & 0 & 0 \\
\hline 9 & Strong Hints & 0 & 0 \\
\hline & Amount & 375 & $100 \%$ \\
\hline
\end{tabular}

Query preparatory term is utterance

contains reference to preparatory conditions as conventionalized in any specific language. The most respondent used query preparatory form in $5^{\text {th }}, 7^{\text {th }}$ and $14^{\text {th }}$ situations. In some contexts of situations, respondents used appropriate form requestive strategy. 


\section{Situation \#5}

When you're studying in the class, suddenly your mobile phone vibrates. You ask for a permission to your lecturer to receive the phone call and go out of the classroom. What would you say? R3: Sir, may I answer my phone? This is urgent.

\section{Situation \#7 \\ One of your lecturers asks you to buy a book while you forget to bring the wallet. So you borrow the money Rp. 50.000 to your friend to buy the book. What would you say? \\ R14: I'm forgetting to bring my wallet; may I borrow your money Rp.50.000 to buy the book?}

\section{Situation \#14}

There are tasks for tomorrow then you want to borrow your friend's notebook to search the material. What would you say?

R17: Hey, may I borrow your notebook, please? I have to search material for my task.

The respondents used query preparatory for conveying a request to older person, it means that the respondents consider usage power (P) when they requested with others. Beside that, they consider ranking of imposition (R) when requesting something. It can be shown in example of situation \#7 above when speaker (respondent) wanted borrowing money to their friend.

Mild Hints is utterance that make no reference to the request proper but are interpretable through the context as request. Beside that, mild hints can be meant less indirect while the speaker does not show his/her want explicitly to hearer. There is an interesting requestive strategy of mild hints that appears in situation \#4, when the student want to admonish their lecturer who smoke in the class, can be shown below:

\section{Situation \#4}

One of your lecturers smoke in the classroom when he explained the material, then you wanted to admonish him because there was a warning not to smoke in the classroom. What would you say?

R9: I'm sorry Sir; would you like to see the warning?

The example of respondents' responses above can be seen that respondent used mild hints strategy. The speaker (students) wanted the hearer (lecturer) not to smoke in the classroom, but the speaker or respondent did not show his wants in his request explicitly. The speaker believed that a boy who was ordered to take a ball will understand his wants. The speaker hid the meaning what he said and made request strategy in mild hints term. Maybe the respondents meant above that the speaker (students) did not want speak exactly about what he/she wanted because the power of the speaker was lower than the hearer (lecturer). Maybe the respondent did not want hurt his lecturer and used mild hints strategy to show his respect. Although social distance between them was casual, the ranking of imposition is high.

The other example usage of mild hints used by respondents can be shown below:

\section{Situation \#11}

One day when your lecturer teaches at 01 p.m., the classroom is very hot. You ask your friend who sit near the window to open the window. What would you say?

R1: It's very hot today, isn't it?

The speaker does not say "open the window!", but the speaker wants his/her friends can understand his/her statement like shown above. When the speaker says "It's very hot today, isn't it?" the speakers shows his/her willing that he/she want his/her friend open the window because the classroom is so hot. Indirectly, he/she orders his/her friend to open the window because he/she maybe wants to show his/her joke by saying like above.

In situation \#6, there is a mild hints term used by respondent which is less different with the example above. The utterance is less threatening the hearer to do something. It 
forces the hearer to respond what speaker wants is repeating the material.

\section{Situation \#6}

Your lecturer does not explain the lesson clearly because his voice is too low to hear. You want your lecturer to repeat the material. What would you say? R1: Excuse me, Sir. I could not hear your voice.

R9: Sorry Miss, your voice so low.

The speaker (students) hides her wants of repeating the material by the lecturer by saying "I could not hear your voice". Maybe the speaker thought that his utterance can be understood by the lecturer. So the respondent used mild hints in this situation to show his wants, although the respondent can use another utterance such as: "Would you repeat the material, Sir?"

Mood derivable is usually used when the speaker wants the hearer to do something in strong position (speaker), because of higher power. This term is started by the verb illocutionary force ahead, such as "do X!". Although usually mood derivable is used for high power, but from the result of questionnaire taken before it shown that usage of mood derivable is also used for equal power. It is because this study is about requestive strategies used by students to the lecturer. In some situation, this term is used by respondent such as the example below:

\section{Situation \#12}

A friend who sits beside you keeps interrupting. You feel annoyed and ask him to not disturb you again. What would you say?

R9: Silent please!

R18: Don't be noisy please!

R25: Please, don't disturb me!

The speaker does not use utterance which is softer than mood derivable, such as using query preparatory. It does not show that the speaker does not respect the hearer, but related to the power because the power between them is equal, the speaker maybe benefitted it to make his wants more effective. The utterance shown above indicates the student did not want his friends to keep interrupt him.

The term of mood derivable that is almost the same with utterance above is shown in situation \#13.

\section{Situation \#13}

You come late to the class. At that time, there are no empty chairs in the classroom. You ask your male friend to take a chair beside your class. What would you say?

R15: Hey, take the chair, please!

R23: Help me please! Do you want to take a chair for me?

Although the social distance between them is close, but the speaker can use mood derivable term for her utterances like it above. She (speaker) maybe does not use her power to threaten her male friend to do her wants, but she may be confident that her friend will not refuse to do because the social distance between them is close.

The last example of mood derivable is in situation \#4. Here is explained that the students want his/her lecturer not to smoke in the classroom.

\section{Situation \#4 \\ One of your lecturer smokes in the classroom when he explains the material, then you want to admonish him because there is a warning not to smoke in the classroom. What would you say? \\ R3: Sorry Sir, don't smoke here!}

In the example above, speaker (student) did not care about his power which was lower power than hearer (lecturer). Speaker used mood derivable for asking hearer to do something, in this situation the speaker wanted the hearer not to smoke in the classroom. The situation like this can use another strategy of request such as query preparatory for example "Could you turn off your cigarette, Sir?", maybe the speaker want shown his utterance explicitly to the lecturer not to smoke in the classroom. Whereas ranking of imposition in this situation is high. 
Obligation statement is the illocutionary point is directly derivable from the semantic meaning of the locution ('You'll have to move that car'). It is the utterances which state the obligation of the hearer to carry out the act, maybe making this term like the utterance in parenthesis is rather hard. The example of this strategy can be shown below:

\section{Situation \#4}

One of your lecturers smokes in the classroom when he explains the material, then you want to admonish him because there is a warning not to smoke in the classroom. What would you say? R8: I'm so sorry Sir, you can't smoke here, and because it's no smoking area and it disturbs us.

R20: I am sorry Sir, you can't smoke here. Because it is no smoking area.

The example above is the situation when the speaker (student) given command to hearer (lecturer) not to smoke in the classroom. This situation not only can use obligation statement but also with use mood derivable for giving confirmation. However maybe speaker want given command softly because in this situation power of hearer (lecturer) is high than the speaker (student). The utterance which used by respondent such as: "you can't smoke here" is direct speech act from the semantic meaning of the locution.

The term of want statement is the utterance expresses the speaker's intentions, desire or feeling. Below are the examples of want statements used by respondent. There is only an example shown, because it is the interesting one to analyze. The utterance tells us that the speaker tries to avoid conflict with the hearer. The speaker avoids threatening the hearer by not saying "do X", the speaker used the softer utterance to express his/her desire. The speaker hoped that the hearer will understand what he/she wants and gave him/her a statement not to blame him/her anymore. Want statement usually uses the words "I hope", "I wish", "I want", etc.

\section{Situation \#3}

Last subject is at 11 a.m. and you have not had breakfast yet, so you are stuffing. Then you ask for a permission to your lecturer to come out the class. What would you say?

R24: Miss, I hope can get time to break, can I?

The example above shows that the speaker (student) realizes that his/her power is lower than hearer (lecturer), so the speaker uses the softer utterance to express his/her willing. Another example shows the different utterance used by respondent to express his/her desire to the hearer.

\section{Situation \#14}

There were tasks for tomorrow then you want to borrow your friend's notebook to look for the material. What would you say?

R23: Sorry, I want to borrow your notebook for doing my task, may I?

\section{Situation \#7}

One of your lecturers asks you to buy a book while you forget to bring the wallet. So you borrow the money Rp. 50.000 to your friend to buy the book. What would you say?

R24: I want borrow your money.

Respondent used not only softer utterance to express his/her desire to hearer who had power that was higher than respondent. But in the example above, respondent used softer utterance for asking something to hearer who had equal power with speaker (respondent). The speaker wanted to borrow something important which had such imposition as borrowing notebook. Sometimes the respondent will use the softer utterance to request something which has such imposition like borrowing money. In this context, respondent can use another strategy of request to express his desire to hearer. But if we see what the speaker wants in this situation, something which has such imposition or it means something which cannot be given easily. 
Suggestory formulae is the sentence contains a suggestion to X ("How about cleaning up?). The term of suggestory formulae is a complex utterance which is seldom used by the respondent. The example below, there are differences between utterance which used by respondent in same situation:

\section{Situation \#1}

If your first lecturer was coming late to class and tended take the next lecture's hours, while the next lesson will hold a test. What would you say?

R6 : Sorry, it's better to make up class because Mr. Dadang will come. R24 : Sorry Sir, time is up. How about you make up class tomorrow? Because next subject would hold a test.

Respondent (speaker) tries to make a suggestion to the lecturer (hearer) to end the teaching and learning process in the classroom because the time is over. Respondent 6 and respondent 24 give suggestion to their lecturer to continue the teaching and learning process in another day because next lesson will hold a test.

While respondent 23 below gives suggestion to the lecturer for asking permission to take the next lecturer's hour to explain the material until finish.

\section{Situation \#1}

If your first lecturer was coming late to class and tended to take the next lecture's hours, while the next lesson will hold a test. What would you say? R23 : Sorry Sir, could you ask to the next lecturer first? Because we have to join the test.

By the utterance above, the hearer will think that time is over and she/he must stop the teaching and learning process. The hearer will not be forced to do something by speaker. The other utterance is shown below:

\section{Situation \#4}

One of your lecturers smokes in the classroom when he explains the material, then you want to admonish him because there is a warning not to smoke in the classroom. What would you say? R21 : I'm sorry Sir but it is no smoking area. It is better for us if you stop smoking.

Suggestory formulae is usage in situation \#4 only one utterance. In this situation, the speaker (student) gives a suggestion for his/her lecturer not to smoke in the classroom. The speaker gives the information if there is prohibition no smoking in the class before the speaker asks the lecturer not to smoke. Maybe the information before a suggestion is used because the speaker (student) did not want offended the hearer (lecturer).

The hedged performatives are the utterances in which the naming of the illocutionary force are modified by hedging expressions ('I would like to ask you to move your car'). The example below is the usage of hedge performative by respondent:

\section{Situation \#15}

You is left behind when your lecturer dictate the material. Then you want to borrow the notes book from your friend when he/she has finished writing. What would you say?

R8: I would like to borrow your notes.

From the example above, hedge performative is usage in situation \#15 only one respondent. In this situation, the speaker (student) want the hearer (lecturer) to borrow his/her friend's book. The utterance does not use interrogative marker, but that is more polite to express what the speaker wants. Whereas the speaker and hearer have the equal power.

Performative and strong hints do not appear in this study. It means they only reach $0 \%$ of data. No respondents use those terms for responding the situations. Performative term is the illocutionary force of the utterances is exlipictly named by the speakers (I'm asking you to move your car). Maybe making this term like the utterance in parenthesis is rather hard. Sometimes the speaker does not use performative term in the campus situation specifically for their 
friends who have equal power with the speaker.

The last requestive strategies is strong hints. Strong hints are utterances containing partial reference to object or element needed for the implementation of the act ('You left the kitchen in a right mess'). Therefore, the strong hints term is not used by EFL learners at the Department of English Education in University of Kuningan in all situation.

The findings of data interview show that social variables such as power, social distance, and ranking of imposition can influence usage requestive strategies. Interview sections were taken from 13 respondents of 25 respondents. They used courtesy when they requested to others. Beside that power, social distance and ranking of imposition are influential when they used requestive strategies. The degree of power ownership is associated with determiner by personal variables such as age and gender.

In this present study there are categories of Power (P) ownership: low, equal and high. The speaker is said to have low power when speaking to a more powerful

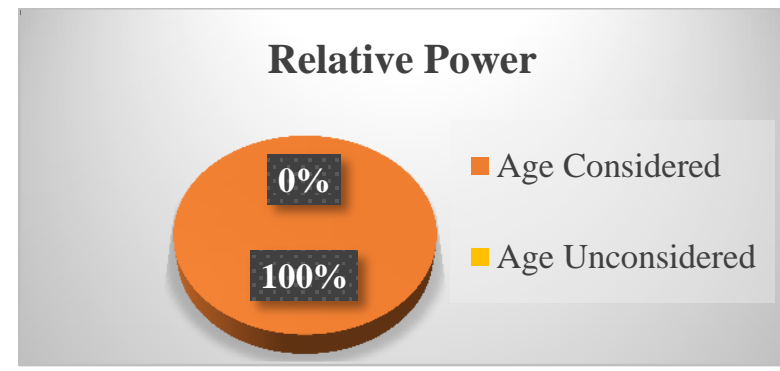

The respondents regardless to the relative power are described in the situations when they responded the questionnaire. Obviously, the respondents are unaware such social variables are not because of their lack of knowledge of information about such social variables since they explicate clearly in the interview making request of course should consider the hearer's power. The degree of power ownership is associated with determined by personal variables such as age and gender. person in terms of personal or social variables characterizing the hearer. In contrast, the speaker is said to have high power when speaker can control the behavior of the hearer and they are equal when no one dominates the others because they share the power equally.

The differences of request strategies used by respondent shown from the level of relative power. First, lower $(-)$ power when the students (respondent) asked for permission to the lecturer to receive the phone. Respondents used courtesy for requesting what they wanted. It can be shown from beginning utterance, they used "I'm sorry sir" and "Excuse me sir", that utterances can be assumed if respondent is aware his/her power is lower than lecturer. Meanwhile second equal (0) power, when the students asked to their friends for borrowing book from them, respondent used courtesy too with "may I" and "please", but sometimes respondent said what his/her want directly. From that example of equal power, it can be assumed that respondents not always used courtesy for conveying of requesting something.

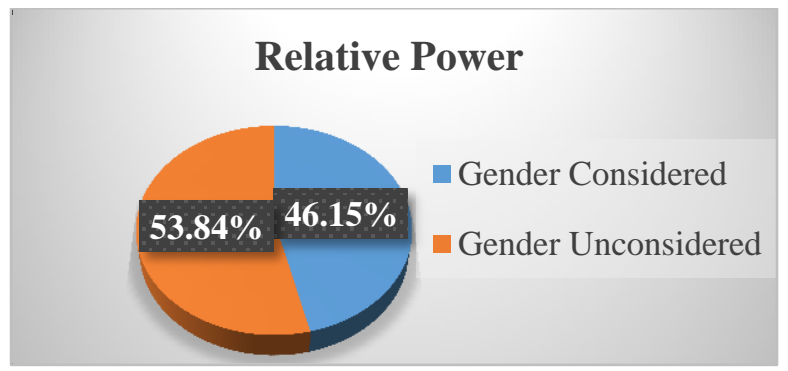

Data finding from interview found the respondents consider courtesy and age when realizing their requests.
"Saya berfikir bahwa memang kesopanan memang sangatlah penting dalam kehidupan kita karena dalam situasi apapun dan kepada siapapun baik itu kepada orang yang lebih tua ataupun kepada yang lebih muda. Pertama kepada yang lebih tua, itu kewajiban kita untuk menghormati mereka. Dan kepada yang lebih muda 
itu kita bisa memberikan contoh kepada mereka bagaimana berkata yang sopan dan ketika kita berkata sopan kepada orang lain maka orang lain pun akan melakukan hal yang sama, mereka akan berkata yang sopan juga."

(I think that indeed civility is important in our lives because in any circumstances and to anyone good to people who are older or younger too. First, it is our duty to honor them. And to the younger we can give an example to them how to say a polite and courteous when we say to others then others will do the same thing, they would have said a polite too.)

The data finding below is respondent's response from interview that considers gender when realizing request strategy.

"Tentu jenis kelamin lawan bicara berpengaruh juga dalam menyampaikan permintaan karena menurut saya menyampaikan permintaan kepada seorang laki laki dan perempuan itu berbeda. Ketika kalau misalnya kita meminta tolong kepada anak perempuan karena saya juga perempuan saya merasa lebih enak tapi kalau misalnya menyuruh kepada seorang laki laki ada perasaan sungkan."

(Certainly the interlocutor's gender is influential when conveying the request because I think conveying the requests to a male and female were different. For example when we ask help to female because I am also a female, I felt better but if I ask to a male there is a feeling of hesitate.)

While, one of male respondent stated that gender unconsidered for conveying request. Because the main things to convey request for him is distance.

"Saya berpendapat bahwa jenis kelamin lawan bicara itu tidak penting karena semuanya sama. Yang terpenting yang membedakan itu adalah kedekatan kita.
Jadi jenis kelamin itu ngga membedakan gitu."

(I argue that the interlocutor's gender is not important because everything is the same. The most important which distinguishes it is our closeness. So gender does not distinguish.)

All of data finding from interview above can be assumed the respondents have prior knowledge of background about politeness norms related to such social variable as relative power. All of respondent used courtesy for delivering a request for something to people who has position lower, equal or higher age than respondents. Meanwhile, for the categories of gender some respondents have no differences to deliver his/her request because they used closeness with the hearer. Although respondent used variation diction, if we compare the utterances above related to the level of relative power described in the three situations, we find significant differences between request strategies used by respondents.

Social distance $(D)$ can be defined as the relative familiarity between the speaker and the hearer. In this study, there are three categories of the degree of relationship: close, casual and distance. The term close is used when the participants have kin relationship or have such very close friendship as brother or member of an in-group who have similar values and ideology or the same agreement between them. While the term distance is used when the participant is not a kinsman, or seeks another dialect or language (Brown and Levinson, 1987) or strangers who meet in public places even colleagues in a workplace but do not know each other. While the term casual is between both conditions, close and distance. It happens when participants know each other but they are unwilling or unable to establish kin relationship.

The diagram below shows that social distance relationship used by respondent when interviewed section. 
Diagram 12. The distribution of social distance

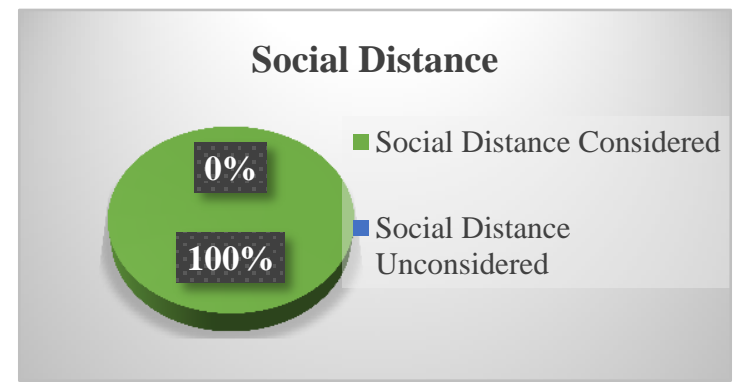

The diagram above shows that all of respondents considered social distance for conveying the request for something. They believed that social distance can be influenced for conveying the request for something.

The result above can be shown from the example statement from some responses of respondent by interview below:

"Ketika kita mempunyai kedekatan dengan seseorang itu akan lebih enak ketika kita akan menyampaikan suatu permintaan terhadapnya, akan tetapi ketika kita ingin meminta sesuatu kepada orang yang tidak dekat dengan kita, pasti kita akan merasa canggung dan sungkan untuk menyatakannya." (When we have propinquity to someone it would be nicer when we convey a request, but when we want to request something to people who are not close with us, we certainly would feel awkward and hesitate to reveal it.) From the reason above the writer assumes the respondents have prior knowledge of background about politeness norm related to such social variable as social distance. The respondent would feel awkward for conveying a request for something to people who close yet with him/her, while respondent when conveying request to people who close with them easily.

Ranking of imposition $(R)$ refers to degree of degree of interference that is imposed by the speaker to the hearer in proportion to the expenditure of services and of goods. In this study, there are three categories of the degree of ranking of imposition: low, medium, and high. The size of the imposition is determined by the size of request and is affected by whatever benefit the hearer might receive and the power of differences and familiarity of the speaker and the hearer. If the request size is higher, it involves a higher imposition on the hearer. If the hearer benefit, if the social distance is lose (high familiarity), or if the hearer's status (power) is lower than the speaker's is perceived as low. The imposition is said medium when the request size is not extremely high or low.

The diagram below shows that level of ranking of imposition used by respondent when interviewed section.

\section{Diagram 13. The distribution of ranking of} imposition

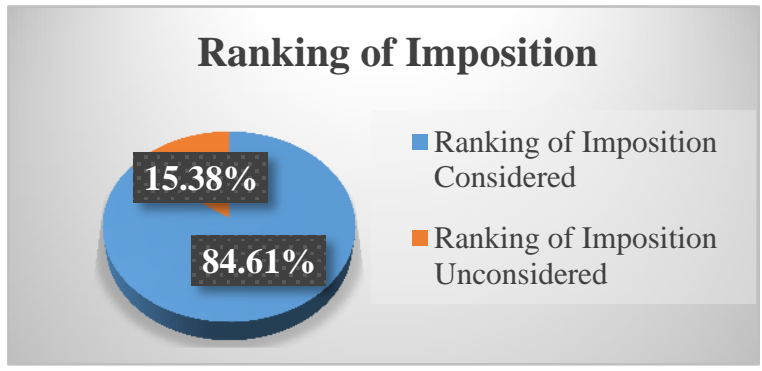

The data above shows that $84.61 \%$ respondents considered ranking of imposition for conveying requesting something, while $15.38 \%$ respondents unconsidered ranking of imposition.

We can see the examples of statement from respondent when they are interviewed that respondents considered ranking of imposition for conveying a request for something.

"Saya pribadi segan ketika meminta sesuatu yang memiliki pembebanan seperti meminjam uang. Hal itu dikarenakan karakteristik seseorang itu berbeda ya. Kedekatan itu tidak menjadi topik utama dalam hal ini, karena ketika kita bercerita kepada orang yang dekat atau tidak dekat dengan kita mengenai hal yang saya butuhkan biasanya saya menceritakan dulu keluhan saya, ketika mereka menawarkan bantuan baru saya terima, tapi saya pribadi justru lebih segan ketika saya harus langsung to the point untuk meminta hal tersebut." 
(I'm certainly unwilling when requesting something which has such imposition like borrowing money. It is because the different characteristics of a person. Yes. The closeness that doesn't become a major topic here, because when we tell to close people or no close people with us about what I need I usually tell my problem before, when they offer of assist so I receive, but I am personally even more unwilling when I have to the point to ask for it.)

From statement above, respondents felt unwilling when conveying requesting something which has such imposition. Thus, the example of that statement was taken from the situation when request borrowing money. They would tell wordy about their request although they tell their request to their friends and someone who has closeness with them.

While, some respondents' unconsidered ranking of imposition for conveying requesting something. There are examples of statement from respondents when interviewed:

"Permintaan meminjam uang merupakan sesuatu hal yang sensitifya. Namun ketika kita memintanya kepada seseorang yang dekat dengan kita, kembali lagi ya dengan kedekatan, kita mungkin bisa saja meminjam uang dengan lebih santai karena mungkin kedekatan tersebut. Namun ketika kita memintanya dengan orang yang belum begitu dekat dengan kita, mungkin itu merupakan sesuatu yang sangat sega untuk kita lakukan. Jadi ketika melakukan hal tersebut, kita harus melihat kepada siapa kita meminta." (Borrowing money is something sensitive. But when we ask someone who close with us, back to propinquity, maybe we just borrow money more relaxed because of that. But when we ask people who have not been close with us, maybe it is something unwilling to do. When we do it, we must see to whom we ask for.) The example statements above can show that any respondents unconsidered ranking of imposition for conveying a request for something. But the respondents used social distance relationship when asked something which has such imposition to others people. The respondent used directly utterance when borrowed money to their friends with to the point of problem. Although the ranking of imposition of money is high imposition, they saw the nominal of that money is not too much so they used directly utterance for it. Maybe when the respondent borrowed much money, they would have said more politely or used conventionally indirect strategy.

\section{CONCLUSION}

This study reveals 15 different situations of requestive strategies that conducted by DCT form. The respondents are from Indonesian EFL learners at Department of English Education in University of Kuningan. There is no different treatment between male and female. This study took 25 respondents included male and female junior students.

The dominant strategies used by Indonesian EFL learners at the Department of English Education in University of Kuningan is query preparatory which reached 243 frequency or $64.8 \%$ of data. The second highest strategy is mild hints with 51 or $13.6 \%$ of data, the third is a mood derivable with 39 or $10.4 \%$ of data, and the forth strategies used by Indonesian EFL learners is obligation statement which the frequency is 28 or $7.5 \%$ of data. Want statement is the fifth highest frequency used by the Indonesian EFL learners with reach 9 or $2.4 \%$ of data. The sixth strategy used by Indonesian EFL learners is a suggestory formulae with 4 or $1.1 \%$. Hedge performative with 1 or $0.3 \%$ of data. Performative and strong hints are the lower strategy which used by Indonesian EFL learners with nothing.

Several of those requests used by respondents while power, social distance and ranking of imposition affect the realization of requestive strategies. In fact, not all of requestive strategies was appropriate used by respondent, but generally those requestive strategies were affected by power, social distance and ranking of imposition. Almost of all respondents can use the appropriate 
requestive strategies, although there are some strategies placed not in the right situation.

\section{REFERENCES}

Austin, J. L. (1962). How to do things with words. Oxford: Oxford University Press.

Barron, A. (2003). Acquisition in interlanguage pragmatic: Learning how to do things with words in a study abroad context. Thesis Doctoral at University Hamburg: John Benjamins.

Blum-Kulka, S., House, J., \& Kasper, G. (1989). Cross cultural pragmatics: Request and apologies. Norwood, Nj: Ablex Publishing Corporation.

Brown, P., \& Levinson, S. C. (1987). Politeness: Some universal in language usage. Cambridge: Cambridge University Press.

Creswell, J. R. (2009). Research design: Quantitative, qualitative and mix method approaches (3 ${ }^{\text {rd }}$ edition). California: Sage Publications Ltd.

Fraenkel, J. R., \& Wallen, N. E. (2009). How to design and evaluate research in education, seventh edition. New York: McGraw-Hsill Higher Education.

House, J. (1989). Politeness in English and German. In Blum-Kulka, S., J. House \& G. Kasper (Ed.), Cross cultural pragmatics: Request and apologies. Norwood, Nj: Ablex Publishing Corporation.

Jalilifar, A., Hashemian, M., \& Tabatabaee, M. (2011). A Cross-sectional study of Iranian EFL learners' request strategies. Journal of Language Teaching and Research, 2 (4), 790-803.

Leech, G. (1983). Principles of pragmatics. New York: Longman Group Limited.

Mohamed, A. (2012). Study of request strategies employed by Libyan and Malay postgraduate students at USM. International Journal of Learning \& Development, 2 (2), 144-151

Mohammadi, M., \& Seyye, H. S. (2014). Native speakers' assessment of (im)politeness of non-native speakers' requests. International Journal of Research Studies in Language Learning, 3 (4), 2340.

Ogiermann, E. (2009). On apologizing in negative and positive politeness culture. Amsterdam: John Benjamin Publishing Company.

Permana, A. (2012). The analysis of politeness strategy in English as a foreign language learners' request. Unpublished research paper. Department of English Education University of Kuningan.

Rue, Y. J., \& Zhang, G. (2008). Request strategies. Amsterdam: John Benjamins Publishing Company.

Schauer, G. (2009). Interlanguage pragmatic development: the study abroad context. York, London: Continuum International Publishing Group.

Searle, R. J. (1979). Expression and meaning: Studies in the theory of speech acts. New York: Cambridge University Press.

Subana, M., Rahardi, R., \& Sudrajat, M. (2000). Statistik pendidikan. Bandung: Pustaka Setia

Sugiyono. (2012). Metode penelitian pendidikan. Bandung: Alfabeta.

Thomas, J. (1995). Meaning in interaction: An introduction to pragmatics. New York: Longman Publishing.

Trosborg, A. (1995). Interlanguage pragmatic: Request, complaints and apologies. Berlin, New York: Mounton Gruyter.

Wahidah, N. (2002). Requestive speech act realizations in Indonesian context: An analysis of power, distance and ranking of imposition behind linguistic behaviors performed by students learning English as a foreign language. Unpublished research paper. Department of English Education of Universitas Pendidikan Indonesia.

Yule, G. (1996). Pragmatics. New York: Oxford University Press. 